Original Research Paper

\title{
Effects of Indoor Air Pollution Among Women in Northeastern, Nigeria
}

\author{
${ }^{1}$ Ngaram Suleman Modu and ${ }^{2}$ Muhammad Sulyman \\ ${ }^{1}$ Department of Physics, Federal University Gashua, Yobe State, Nigeria \\ ${ }^{2}$ Department of Biological Science, Federal University Gashua, Yobe State, Nigeria
}

Article history

Received: 17-04-2020

Revised: 07-07-2020

Accepted: 15-07-2020

Corresponding Author:

Ngaram Suleman Modu

Department of Physics, Federal University Gashua, Yobe State, Nigeria

Email: ngaramsuleiman@ fugashua.edu.ng

\begin{abstract}
This research investigated the effects of indoor air pollution among women, in Northeastern, Nigeria, indoor air pollution refers to the physical, chemical and biological characteristics of air in the indoor environment, which include a home, building, an institution or commercial facility. Study was carried out in five wards: Benen Bayero, Karamar Tanda, Asibitin Agana, Goni Aji Street and Abdullahi Masaba Street. Questionnaires containing personal information, health status and household circumstances of respondents were distributed randomly (50 in each study area) for data collection. Kerosene is used in less than $5 \%$ of the households and charcoal was used in about a third of the household. Cooking outdoor is linked to coughing, burns, confusion, cataract, pneumonia and bronchitis among women, as well as several respiratory and eye related problems. Moreover, cataract and asthma were found to be more prevalent among women cooking indoors.
\end{abstract}

Keywords: Indoor, Air Pollution, Women, Gashua, Northesten

\section{Introduction}

Indoor air pollution refers to the physical, chemical and biological characteristics of air in the indoor environment, which include a home, building, an institution or commercial facility (Igboanugo and Ajieh, 2017). The history of indoor air pollution dates back to the first human dwelling and use of fire (Behera and Balamugesh, 2005). Combustion pollutants are common contaminants of indoor and outdoor environment (Mehta, 2004) and include carbon-monoxide, nitrogen-dioxide, Sulphur-dioxide, aldehydes, particles etc. (Nachreiner et al., 1976). Use of solid fuels for cooking and heating is regarded as a major global contributor of indoor air pollution. Almost half of the world population uses solid fuels such as dung, wood, agricultural residues and coal to cook (Langbein, 2017). When used in simple cooking stoves, these fuels emit substantial amounts of toxic pollutants (Mohamed et al., 1995). In households with limited ventilation (as is common in many developing countries), exposures experienced by household members, particularly women and young children who spend a large proportion of their time indoors, have been estimated to be much higher than the (World Health Organization (WHO) set limits (Smith, 1987).

Pollutants from indoors can be natural, man-made or some that result from combustion. Major source of natural pollutants such as radon and biological contaminants include; earth and rock, under buildings, ground water, house dust bedding, wet or moist surface, carpets and home air conditions (Agrawal and Yamamoto, 2015). The major pollutants from combustion are Carbon monoxide (CO) and Repairable combustion Particles (RSP), which are caused by wood-burning stoves, fire places, tobacco smoke, wood or coal stoves and home heating equipment's (de Koning et al., 1985). The man-made pollutants which include; asbestos, volatile organic chemicals, formaldehyde and lead, are major contributors to indoor air pollution worldwide (Hynes et al., 2003). The sources of these pollutants are thermal insulation, floor materials, dry-cleaned clothing, moth balls, pesticides and aerosol sprays (Gilliland et al., 1999).

Several researches have mentioned the health problems associated with indoor air pollutants, these mainly include lung cancer, allergies and asthma (Leikauf, 2002), eye related health conditions, nose and throat irritants, pneumonia, drowsiness, respiratory tract damage, tonsillitis, anaemia and confusion (Arborelius and Bremberg, 2001). This study investigated the effects of indoor air pollution in Northeastern, Nigeria.

\section{Biomass Fuel and Effects on Women}

Biomass fuels are used by about half the world's population as a major, often as the only source of domestic energy for cooking and heating. Women in Nigeria are commonly exposed to biomass smoke from open fire cooking at home, due to frequent cooking and spending most of their time indoor. Poor combustion ability of some stoves produce significant amount of 
pollutants that adversely affect the health of women (Fullerton et al., 2008). Major pollutants emitted as a result of burning biomass as fuel includes; carbon monoxide and formaldehyde. Exposure to large amounts of these pollutants present gives the significant amount of respiratory problems. The major health problems associated with cooking among women in African countries is respiratory related and many researchers have linked this to biomass smoke during cooking activities (de Koning et al., 1985; World Health Organization, 2016; IARC, 1988).

\section{Kerosene Fuel and Effects on Women}

Cooking by use of kerosene is widespread in many developing countries, especially in urban populations, where biomass needs to be purchased and electricity and LPG are expensive or unreliable. Kerosene combustion emits many potentially health-damaging pollutants, including Particulate Matter (PM), carbon monoxide, polycyclic aromatic hydrocarbons and volatile organic compounds (Leikauf, 2002). Research has been conducted on cooking with kerosene, that leads to an increased risk of tuberculosis and burn (Agrawal and Yamamoto, 2015).

\section{Materials and Methods}

\section{Study Area}

Gashua $\left(12^{\circ} 52^{\prime} 26.33^{\circ} \mathrm{N}, 11^{\circ} 02^{\prime} 26.05^{\circ} \mathrm{E}\right)$ is located in Yobe state, North-eastern Nigeria, with around 125,000 people Sabongari is a densely populated area in Gashua constituting about $35 \%$ of the total number of residents (https://en.m.wikipedia.org). The residents are predominantly low and middle income families, consisting of small scale traders, farmers and civil servants.

The study area was divided into five (5): A, B, C, D and E to represent Benen Bayero, Karamar Tanda, Asibitin Agana, Goni Aji Street and Abdullahi Masaba Street respectively. Each area has at least 60 - 80 houses.

\section{Data Collection}

A total of 250 structured questionnaires containing personal information, health status and household circumstances of respondents were distributed randomly (50 in each study area). The study was conducted over a period of 4 weeks from $1^{\text {st }}-30^{\text {th }}$ September 2018. The structured questionnaires were administered to the respondents during a face to face interview. Information was obtained in line with the study objectives, with the consent of the respondents in order to obtain valid responses. The questionnaire was subjected to test before use and modified as requested before the start of the study. The questionnaire was administered in English and Hausa Languages.

\section{Results and Discussion}

The results of this research were obtained after the data was collected through administered questionnaire by the respondents. 250 participants were engaged in this exercise (mean age is 40.6 years representing 16.2\%), $83.6 \%$ of them were married (Table 1 ).

Majority of women reported cooking outdoors $(66.3 \%)$ as against those that reported cooking indoors $(33.7 \%)$. Firewood has the highest percentage of use both indoors and outdoors (50.6\%), with $38.2 \%$ using firewood outdoors and $12.4 \%$ using firewood indoors. Kerosene however, has the lowest rate of use $(4.4 \%)$ among women, with only $2.2 \%$ reported use in both case, $6.6 \%$ reported use of firewood and kerosene while $9.7 \%$ use kerosene and charcoal $(n=37,16.4 \%)$, (Table 2).

\section{Health Effect Associated with Cooking Smoke}

Asthma and tonsillitis were the most common health problem reported by the respondents with $14.4 \%$ each. Both of these medical conditions have to do with respiratory tract. The second categories of health problem reported were cataract and Conjunctiva F.B. with $(6.8 \%)$ and (10.4\%) respectively. These categories are more related to the eye. The least common which include Cornea F.B (5.6\%), bronchitis $(7.6 \%)$, pneumonia $(12.4 \%)$, tuberculosis $(11.6 \%)$ and laryngitis $(8.4 \%)$, have also been reported, with some respiratory and others visionary related (Table 3 ).

Pneumonia is more vulnerable among women who cook outdoors $(20.80 \%)$, followed by asthma (18.12\%) and laryngitis $(14.80 \%)$. On the other hand, Cataract $(27.60 \%)$ and asthma (19.70\%) were reported to be prevalent among women cooking indoors. The least prevalent disease conditions reported in both cases (indoor and outdoor) were Tuberculosis (3.55\%), Conjunctiva F.B (7.5\%), Cornea F.B (7.11\%) and Tonsillitis (8.00\%). (Table 4).

Table1: Socio-demographic characteristics of all participants

\begin{tabular}{lcc} 
Table1: Socio-demographic characteristics of all participants \\
\hline \multicolumn{3}{c}{ Description $\mathrm{n}=250$} \\
Characteristics & Frequency & Percentage (\%) \\
\hline Gender & 250.0 & 100.0 \\
Female & 0.0 & 0.0 \\
Male & & \\
Source of income & 96.0 & 38.4 \\
Traders & 114.0 & 45.6 \\
Farmers & 32.0 & 12.8 \\
Civil servant & 8.0 & 3.2 \\
Hunting & & \\
Level of education & 56.0 & 22.4 \\
None & 54.0 & 21.6 \\
Primary & 111.0 & 44.4 \\
Secondary & 29.0 & 11.6 \\
Post-secondary & & \\
Marital status & 0.0 & 0.0 \\
Single & 209.0 & 83.6 \\
Married & 41.0 & 16.4 \\
Divorce & & \\
Age & 40.6 & 16.2 \\
Mean SD & & \\
\hline SD Standard Deviation &
\end{tabular}

$\mathrm{SD}=$ Standard Deviation 
Table 2: Location of the kitchen among the 250 participants

\begin{tabular}{|c|c|c|c|c|c|c|}
\hline \multirow[b]{3}{*}{ Type of primary fuel } & \multicolumn{4}{|c|}{ Location of the kitchen } & \multirow[b]{3}{*}{ Total participant } & \multirow[b]{3}{*}{ Total percentage $(\%)$} \\
\hline & \multicolumn{2}{|c|}{ Outdoor cooking } & \multicolumn{2}{|c|}{ Indoor cooking } & & \\
\hline & Frequency & Percentage $(\%)$ & Frequency & Percentage $(\%)$ & & \\
\hline Kerosene & 5 & 2.2 & 5 & 2.2 & 10 & 4.4 \\
\hline Charcoal & 31 & 14.0 & 21 & 9.4 & 52 & 23.4 \\
\hline Agricultural remnant & 12 & 5.3 & 0 & 0.0 & 12 & 5.3 \\
\hline Firewood & 86 & 38.2 & 28 & 12.4 & 114 & 50.6 \\
\hline Kerosene and charcoal & 10 & 4.4 & 12 & 5.3 & 22 & 9.7 \\
\hline Firewood and kerosene & 5 & 2.2 & 10 & 4.4 & 15 & 6.6 \\
\hline Total number & 149 & 66.2 & 101 & 33.8 & 250 & 100.0 \\
\hline
\end{tabular}
$n=250$

Table 3: Heath problems reported by the respondents

\begin{tabular}{llr}
\hline Condition & Frequency & Percentage $(\%)$ \\
\hline Asthma & 36 & 14.4 \\
Bronchitis & 19 & 7.6 \\
Pneumonia & 31 & 12.4 \\
Laryngitis & 21 & 8.4 \\
Cataract & 17 & 6.8 \\
Conjunctiva F. B & 26 & 10.4 \\
Cornea F. B & 14 & 5.6 \\
Tonsillitis & 36 & 14.4 \\
Tuberculosis & 29 & 11.6 \\
Others & 21 & 8.4 \\
\hline
\end{tabular}

$n=250$

Table 4: Health conditions associated with kitchen location (outdoor/indoor)

\begin{tabular}{|c|c|c|c|c|c|c|}
\hline \multirow[b]{3}{*}{ Conditions } & \multicolumn{4}{|c|}{ Kitchen location } & \multirow[b]{3}{*}{ Total frequency $n=250$} & \multirow[b]{3}{*}{ Total percentage $(\%)$} \\
\hline & \multicolumn{2}{|c|}{ Outdoor $n=149$} & \multicolumn{2}{|c|}{ Indoor $n=101$} & & \\
\hline & Frequency & Percentage $(\%)$ & Frequency & Percentage $(\%)$ & & \\
\hline Asthma & 27 & 18.12 & 15 & 19.70 & 42 & 18.67 \\
\hline Brochitis & 14 & 9.40 & 7 & 9.20 & 21 & 9.33 \\
\hline Pneumonia & 31 & 20.80 & 9 & 11.80 & 40 & 17.78 \\
\hline Laryngitis & 22 & 14.80 & 4 & 5.20 & 43 & 19.11 \\
\hline Catarrh & 16 & 10.73 & 21 & 27.60 & 20 & 8.89 \\
\hline Conjunctiva F. B & 13 & 8.72 & 4 & 5.20 & 17 & 7.56 \\
\hline Cornea F. B & 11 & 7.40 & 5 & 6.70 & 16 & 7.11 \\
\hline Tuberculosis & 3 & 2.01 & 5 & 6.70 & 8 & 3.55 \\
\hline Tonsillitis & 12 & 8.02 & 6 & 7.90 & 18 & 8.00 \\
\hline Total & 149 & 100.00 & 101 & 100.00 & 250 & 100.00 \\
\hline
\end{tabular}

This shows that outdoor cooking has high rate of respiratory problems $(73.15 \%)$ and low rate of eye related problems (26.85\%), rejecting the null hypothesis (outdoor cooking cannot lead to respiratory problems among women) and adopting the alternative hypothesis.

\section{Conclusion}

This study found that use of firewood as fuel is practiced in nearly all households surveyed either as primary or secondary cooking fuel. This is consistent with other findings of a high rate of firewood use in rural areas (Gujba et al., 2015). Kerosene was used in less than 5\% of the households, while charcoal was used in about a third of the households. Stacking of fuels (using more than one cooking fuel) occurred in few households with an average of $16.3 \%$. In contrast, (Ozoh et al., 2018) conducted a similar study in Lagos and reported high percentage of kerosene $(91.5 \%)$ and charcoal $(30 \%)$ use. This result also found prevalence of pneumonia among women using kerosene and solid fuel, which is in line with the World Health Organization (WHO) report on high risk of pneumonia among women cooking with kerosene and solid fuel (World Health Organization, 2016). In this study, eye related conditions such as cataract conjunctiva F. B were reported to have low prevalence among women, 
although these are more pronounced among elderly women aged 41-50, 61-70 and 71-80.

\section{Ethics}

This article is original and contains unpublished material. The corresponding author confirms that all of the other authors have read and approved the manuscript and no ethical issues involved.

\section{Author's Contributions}

Ngaram Suleman Modu: Conceptualization of the research Ideology, identification of problem statement, aim and objectives, data gathering and analysis.

Sulyman Muhammad: Contribution to the literature relating to effects of pollution.

\section{Reference}

Agrawal, S., \& Yamamoto, S. (2015). Effect of indoor air pollution from biomass and solid fuel combustion on symptoms of preeclampsia/eclampsia in Indian women. Indoor Air, 25(3), 341-352. https://doi.org/10.1111/ina.12144

Arborelius, E., \& Bremberg, S. (2001). Child HealthCentre-Based Promotion of a tobacco-free environment A Swedish Case Study; International Journal of Environmental Promotion 16 (3) pp.245-254.

https://doi.org/10.1093/heapro/16.3.245

Behera, D., \& Balamugesh, T. (2005). Indoor air pollution as a risk factor for lung cancer in women. JAPI, 53, 190-192.

de Koning, H. W., Smith, K. R., \& Last, J. M. (1985). Biomass fuel combustion and health. Bulletin of the World Health Organization, 63(1), 11. https://www.ncbi.nlm.nih.gov/pmc/articles/pmc2536 350/

Fullerton, D. G., Bruce, N., \& Gordon, S. B. (2008). Indoor air pollution from biomass fuel smoke is a major health concern in the developing world. Transactions of the Royal Society of Tropical Medicine and Hygiene, 102(9), 843-851. https://doi.org/10.1016/j.trstmh.2008.05.028

Gilliland, F. D., McConnell, R., Peters, J., \& Gong Jr, H. (1999). A theoretical basis for investigating ambient air pollution and children's respiratory health. Environmental Health Perspectives, 107(suppl 3), 403-407. https://doi.org/10.1289/ehp.99107s3403

Gujba, H., Mulugetta, Y., \& Azapagic, A. (2015). The household cooking sector in Nigeria: Environmental and economic sustainability assessment. Resources, 4(2), 412-433.

https://doi.org/10.3390/resources4020412
Hynes, H. P., Brugge, D., Osgood, N. D., Snell, J., Vallarino, J., \& Spengler, J. (2003). "Where does the damp come from?" Investigations into the indoor environment and respiratory health in Boston public housing. Journal of Public Health Policy, 24(3-4), 401-426. https://doi.org/10.2307/3343385

Igboanugo, A. C., \& Ajieh, M. U. (2017). Design and construction of a biomass stove for cooking in rural settlements in Nigeria. Nigerian Research Journal of Engineering and Environmental Sciences, 2(2), 351-359.

https://www.cabdirect.org/cabdirect/abstract/2019 3112855

IARC. (1988). Occupational exposures in petroleum refining; crude oil and major petroleum fuels. IARC monographs on the evaluation of carcinogenic risks to humans, 45.

Langbein, J. (2017). Firewood, smoke and respiratory diseases in developing countries-the neglected role of outdoor cooking. PloS One, 12(6), e0178631. https://doi.org/10.1371/journal.pone.0178631

Leikauf, G. D. (2002). Hazardous air pollutants and asthma. Environmental Health Perspectives, 110(suppl 4), 505-526. https://doi.org/10.1289/ehp.02110s4505

Mehta, S. (2004). Characterizing exposures to indoor air pollution from household solid fuel use (India). https://elibrary.ru/defaultx.asp?rpage=https://www.e library.ru/item.asp?id=5458173

Mohamed, N., Odhiambo, J., Nyamwaya, J., \& Menzies, R. (1995). Home environment and asthma in Kenyan schoolchildren: A case-control study. Thorax, 50(1), 74-78.

https://doi.org/10.1136/thx.50.1.74

Nachreiner, D. J. Carpenter, C. P. King, J. M. Sullivan, L. J. (1976). The Chemical Hygiene Fellowship, Carnegie-Mellon Institute of Research, CarniegieMellon University, Pittsburgh, Pennslylvania 15213 USA.

Ozoh, O. B., Okwor, T. J., Adetona, O., Akinkugbe, A. O., Amadi, C. E., Esezobor, C., ... \& Mortimer, K. (2018). Cooking fuels in Lagos, Nigeria: Factors associated with household choice of kerosene or Liquefied Petroleum Gas (LPG). International Journal of Environmental Research and Public Health, 15(4), 641. https://doi.org/10.3390/ijerph15040641

Smith, K.R. (1987). Tuberculosis and indoor biomass and kerosene use in Nepal: A case-control study. Environ. Health Perspect. 2010, 118, 558-564. https://doi.org/10.1289/ehp.0901032

World Health Organization. (2016). Malaria microscopy quality assurance manual-version 2. World Health Organization. ISBN-10: 9241549394. 